\title{
Who are your Students in Writing?
}

\author{
Rika Damayanti ${ }^{1}$, Mulyadi Mulyadi ${ }^{2}$, Baginda Simaibang ${ }^{3}$ \\ ${ }^{1}$ SMA Negeri 1 Sekayu \\ ${ }^{2}$ Universitas PGRI Palembang
}

\begin{tabular}{l}
\hline Article Info \\
\hline Article history: \\
Received Jul $12^{\text {th }}, 2021$ \\
Revised Aug $14^{\text {th }}, 2021$ \\
Accepted Aug $30^{\text {th }}, 2021$ \\
\hline
\end{tabular}

\section{Keyword:}

Personality Types

Learning Styles

Writing Ability

\begin{abstract}
This study investigated the correlation among personality types, learning styles and writing ability to the eleventh grade students at Senior High School Number 1 Sekayu. The aims of this study were to measure the correlation between personality types and writing ability, the correlation between learning styles and writing ability, the correlation between personality types and learning styles, and the correlation among personality types, learning styles, and writing ability. In this study, the writer used purposive technique sampling. The data were collected by using questionnaire and test. The data were analyzed by using r-product moment and multiple regressions. The findings of this study are: 1 . There was not any significant correlation between personality types and writing ability of the eleventh grade students at Senior High at Senior High School 1 Sekayu. 2. There was not any significant correlation between learning styles and writing ability of the eleventh grade students at Senior High School 1 Sekayu. 3. There was significant correlation between learning styles and writing ability of the eleventh grade students at at Senior High School 1 Sekayu. 4. There were not any significant correlations among personality types, learning styles, and writing ability of the eleventh grade students at Senior High School Number 1 Sekayu. It could be concluded that personality types and learning styles were not correlated significantly with students' writing ability.
\end{abstract}

(C) 2021 The Authors. Published by IICET.

This is an open access article under the CC BY-NC-SA license

(https://creativecommons.org/licenses/by-nc-sa/4.0

\section{Corresponding Author:}

Rika Damayanti

SMA Negeri 1 Sekayu

Email: rikaromza@gmail.com

\section{Introduction}

As a compulsory subject, English is learned within certain duration by students as EFL. [1], "English has become the priority in a country where English becomes a foreign language such as in Indonesia" . However, the fact says that the capability of Indonesians in using English is not high proficient yet. Based on [2], the Indonesians proficiency is in the 32nd rank of seventy-two countries. It has reflected that the capability in using English is not high even difficult to master it because of many obstacles including the skills. As people know that every language is composed of skills to support communication among people as well as English. [3] expressed speaking, writing, listening, and reading are becoming the four basics skill in English. All of these skills have their own features and difficulties including writing faced by learners. [4] stated, "Writing has always been considered as an important skill in the teaching and learning of English as a Foreign Language (EFL)" . As a matter of fact, English is still coming into existence of difficulties by students. They have to be mastered it as an initial preparation to communicate among people instead speaking. 
As foreign learners, students are not only demanded to construct a language in form of spoken but also the written form in English. Writing is quite different from speaking although both of them are used to express idea in doing an interaction. [5] asserted that both writing and speaking are productive skill but they are different. [6] confirmed another aspect of communication is written word (writing). [7] In addition, informed that writing is the most difficult skill for ESL learner and it also is proven by [8] that "Indonesian misunderstanding frequently take place in written English". It depicts that writing is tricky and needs to be understood well-constructed. Having a good composition and communication in English is also affected by the writers' personality and the style in learning.

Students' personality is having a very assential role in students' writing ability. Personalityy is a way of people think, feel, and interact among people or interlocutors in communication field, writing as well. [9], personality refers to human variations in characteristic patterns of thought, emotion and actions. [10] that a distinctive way of thinking, feeling, and acting is personality. Personality accepts attitudes, attitudes and views and is most clearly articulated in relationships with other individuals. [11] found that there was significance difference writing achievement between introvert and both of extrovert and ambivert types. Meanwhile, there was not significance difference writing achievement between extrovert and ambivert types [12]. Furthermore, personality is being a crucial aspect which can affect students' writing performance.

Further, all writers are introverts and that the writing life is a lonely one. Then consider joining a writing community or workshop if you are an extrovert, someone who is refreshed by spending time in small or large groups of individuals. Intend to go to conferences and meet people who are as fond of writing as you are. Create your network so that you will have people to call upon who know how to support you when your writing soul longs to be fed [13].

In addition, besides personality of students which found while the writing is teaching at Senior High School is that their learning styles. These styles influence students' writing ability. Learning style is a way or ways of students in learning. It shows how students get the material or understand what they learned. [14] proved that there was a weak significant correlation between the students' learning styles and students' recount writing achievement.

\section{Method}

This study employed a quantitative research method. The research design used is correlational design as follows:

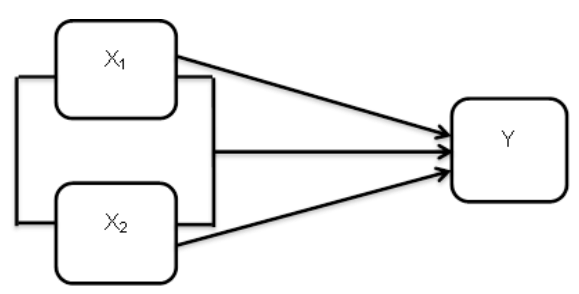

Figure 1. The correlational design

Information:

X1 : Personality Types

$\mathrm{X} 2$ : Learning Styles

Y : Writing Ability

Figure shows how Augmented Reality-based learning was compared find out how much distribution of correlation between independent variable (X1) and dependent variable (Y); Independent variable (X2) and dependent variable (Y); independent variable (X1) and independent variable (X2) and the correlation among independent variable $(\mathrm{X} 1, \mathrm{X} 2)$ and dependent variable $(\mathrm{Y})$. This research will answer the formulation of the problem, hypothesis test and concluded the correlation between personality types (X1) and writing ability (X2) toward reading achievement (Y).

The study conducted in Senior High School Number 1 Sekayu. The sample was purposive techniques sampling. The researcher decides what needs to be known and sets out to find people who can and are willing to provide the information by virtue of knowledge or experience. Therefore, the object of this study will be the students of XI MIPA 1 in academic year 2020/2021 which consists of thirty students. They were chosen because they have learned recount text based on the information given and this class is the most conducive class than the others. 
The research data were obtained by distributing two questionnaires to the students. First, the questionnaire is related to personality types and the second is a questionnaire of learning styles from field trial results. The trial results were analyzed using Pearson Product Moment Formula for each question of personality types and learning styles questionnaire. The instrument's reliability in this study was obtained from Cronbach's alpha testing on personality and learning styles outcome data. Students' personality types and learning styles were analyzed through descriptive analysis and hypothesis testing consisting of the normality, homogeneity, linearity, r-product moment, and multiple regression test.

\section{Results and Discussions}

The study started by having the data of students' personality types and learning styles trough completing questionnaire. The data were analyzed and described on the basis of their frequency, mean, medium, mode, standard deviation, variance, range, minimum, and maximum score. Then, to determine the classification and categories of students' personality types, learning styles outcomes, and writing ability, descriptive analysis was performed. Based on the data collected, the findings revealed as the following table:

Table 1. Personality Types Questionnaire Summary

\begin{tabular}{cccc}
\hline No. & Personality Types & Frequency & Percentage \\
\hline 1 & Extrovert & 10 & $33 \%$ \\
\hline 2 & Introvert & 20 & $67 \%$ \\
\hline & Total & 30 & $100 \%$ \\
\hline
\end{tabular}

Based on the Table above, it could be seen that there were $33 \%$ or 10 students who belong to extrovert in personality types. Meanwhile, $67 \%$ or 20 students belong to introvert.

Table 2. Description Statistic of Personality Types

\begin{tabular}{|c|c|c|}
\hline \multicolumn{3}{|c|}{ Statistics } \\
\hline \multicolumn{3}{|c|}{ Personality Types } \\
\hline \multirow[t]{2}{*}{$\mathrm{N}$} & Valid & 30 \\
\hline & Missing & c \\
\hline \multicolumn{2}{|c|}{ Mean } & 81.27 \\
\hline \multicolumn{2}{|c|}{ Std. Error of Mean } & 1.440 \\
\hline \multicolumn{2}{|c|}{ Median } & 81.50 \\
\hline \multicolumn{2}{|c|}{ Mode } & 74 \\
\hline \multicolumn{2}{|c|}{ Std. Deviation } & 7.887 \\
\hline \multicolumn{2}{|c|}{ Variance } & 62.202 \\
\hline \multicolumn{2}{|c|}{ Range } & 30 \\
\hline \multicolumn{2}{|c|}{ Minimum } & 65 \\
\hline \multicolumn{2}{|c|}{ Maximum } & 95 \\
\hline \multicolumn{2}{|c|}{ Sum } & 2438 \\
\hline
\end{tabular}

Table 3. Learning Styles Questionnaire Summary

\begin{tabular}{cccc}
\hline No. & Learning Styles & Frequency & Percentage \\
\hline 1 & Visual & 18 & $60 \%$ \\
\hline 2 & Auditory & 8 & $27 \%$ \\
\hline 3 & Kinaesthetic & 4 & $13 \%$ \\
\hline & Total & 30 & $100 \%$ \\
\hline
\end{tabular}

Based on the Table above, it could be seen that there were $60 \%$ or 18 students who belong to visual in learning styles. Meanwhile, $27 \%$ or 8 students belong to auditory. In addition, there were $13 \%$ or 4 students belong to kinesthetic. 
Table 4. Description Statistic of Learning Styles

\begin{tabular}{|l|r|r|}
\hline \multicolumn{2}{|c|}{ Statistics } \\
\hline Learning Styles & \multicolumn{1}{|c|}{} \\
\hline $\mathrm{N}$ & Valid & 30 \\
\cline { 2 - 3 } & Missing & 0 \\
\hline Mean & & 99.83 \\
\hline Std. Error of Mean & 1.304 \\
\hline Median & 100.00 \\
\hline Mode & 100 \\
\hline Std. Deviation & 7.144 \\
\hline Variance & 51.040 \\
\hline Range & 35 \\
\hline Minimum & 86 \\
\hline Maximum & 121 \\
\hline Sum & 2995 \\
\hline
\end{tabular}

Based on the Table above, it found that mean score of learning styles is 99,83 , median is 100,00 , mode is 100 , standard deviation is 7,144, variance is 51,040 , range is 35 , minimum score is 86 , and maximum score which is gotten by the students is 121 .

Table 5. Students' Writing Ability Test Summary

\begin{tabular}{cccc}
\hline No. & Writing Ability & Frequency & Percentage \\
\hline 1 & Excellent & 13 & $43 \%$ \\
\hline 2 & Very Good & 12 & $40 \%$ \\
\hline 3 & Good & 5 & $17 \%$ \\
\hline 4 & Poor & 0 & $0 \%$ \\
\hline & Total & 30 & $100 \%$ \\
\hline
\end{tabular}

Based on the Table above, it could be seen that there were $43 \%$ or 13 students who got excellent in writing ability. Meanwhile, $40 \%$ or 12 students got very good. In addition, there were $17 \%$ or 5 students got good and no performed poor in writing.

Table 6. Description Statistic of Learning Styles

\begin{tabular}{|l|r|r|}
\hline \multicolumn{2}{|c|}{ Statistics } \\
\hline Writing Ability & Valid & 30 \\
\cline { 2 - 3 } & Missing & 16 \\
\hline Mean & 13.20 \\
\hline Std. Error of Mean & .397 \\
\hline Median & 13.00 \\
\hline Mode & 16 \\
\hline Std. Deviation & 2.172 \\
\hline Variance & 4.717 \\
\hline Range & 6 \\
\hline Minimum & 10 \\
\hline Maximum & 16 \\
\hline Sum & 396
\end{tabular}

Based on the Table above, it found that mean score of writing ability is 13,20 , median is 13,00 , mode is 16 , standard deviation is 2,172 , variance is 4,717 , range is 6 , minimum score is 10 , and maximum score which is gotten by the students is 16 . 
After getting the data of students' personality types, learning styles, and writing ability, the researcher conducted the data analysis to find out the normality, linearity, and homogeneity.

Table 7._Summary of Normality Data Testing

\begin{tabular}{lrrrr}
\hline & Tests of Normality & & & \\
& \multicolumn{3}{c}{ Kolmogorov-Smirnov $^{\mathrm{a}}$} \\
\cline { 2 - 5 } & Statistic & df & \multicolumn{1}{c}{ Sig. } \\
\hline Personality Types & .138 & 30 & .152 \\
\hline Learning Styles & .147 & 30 & .099 \\
\hline a. Lilliefors Significance Correction & & & \\
\hline
\end{tabular}

Table 7 shows that p-output is 0.152 and 0.099 . This value is higher than 0.05 . Therefore, the data used in this study are in normal distribution.

Table 8. Summary of Homogeneity Data Testing

\begin{tabular}{|c|c|c|c|}
\hline \multicolumn{4}{|c|}{ Test of Homogeneity of Variances } \\
\hline Nilai & & & \\
\hline Levene Statistic & df1 & $\mathrm{df2}$ & Sig. \\
\hline 3.276 & 1 & 58 & .075 \\
\hline
\end{tabular}

Table shows that p-output is 0.075 . This value is higher than 0.05 . Therefore, the data used in this study are homogeneous.

Table 9. Summary of Linearity Data Testing of Personality Types and Writing Ability

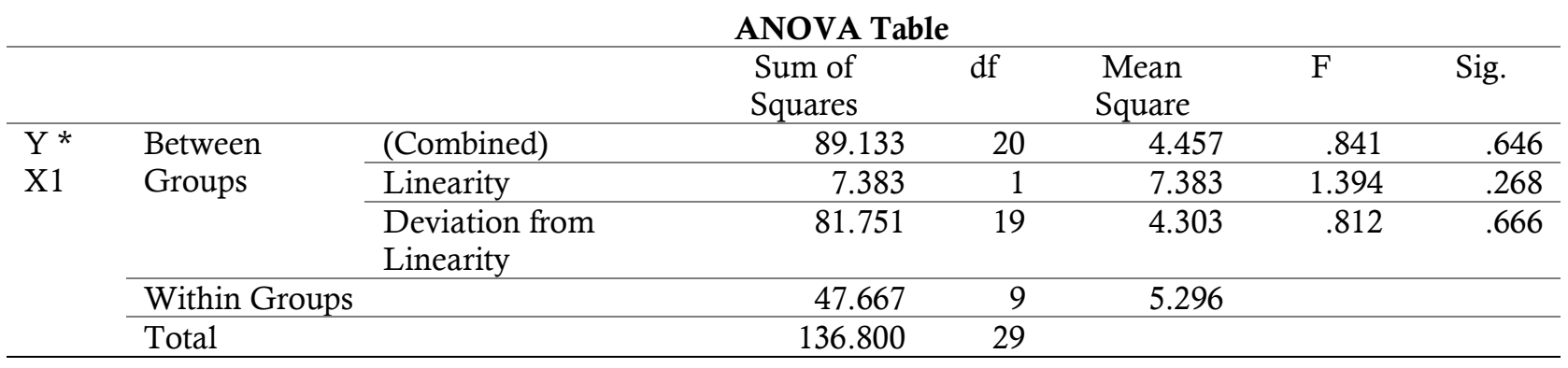

Table 10. Table Summary of Linearity Data Testing of Personality Types and Writing Ability

\begin{tabular}{|c|c|c|c|c|c|c|c|}
\hline \multicolumn{8}{|c|}{ ANOVA Table } \\
\hline & & & $\begin{array}{l}\text { Sum of } \\
\text { Squares }\end{array}$ & $\mathrm{df}$ & $\begin{array}{l}\text { Mean } \\
\text { Square }\end{array}$ & $\mathrm{F}$ & Sig. \\
\hline $\mathrm{Y}^{*}$ & Between & (Combined) & 70.133 & 17 & 4.125 & .743 & .720 \\
\hline \multirow[t]{4}{*}{$\mathrm{X} 2$} & Groups & Linearity & 5.232 & 1 & 5.232 & .942 & .351 \\
\hline & & $\begin{array}{l}\text { Deviation from } \\
\text { Linearity }\end{array}$ & 64.901 & 16 & 4.056 & .730 & .726 \\
\hline & Within Groups & & 66.667 & 12 & 5.556 & & \\
\hline & Total & & 136.800 & 29 & & & \\
\hline
\end{tabular}

Table 9 and 10 show that p-output is 0.268 and 0.351 . This value is higher than 0.05 . Therefore, the data used in this study are linear.

The analysis of the correlation between personality types and writing ability used correlation coefficient in SPSS 20. The result of the correlation coefficient was presented in the following Table. 
Table 11. Summary of Correlation between Personality Types and Writing Ability

\begin{tabular}{llrrr}
\hline & \multicolumn{2}{c}{ Correlations } & & Writing Ability \\
\hline \multirow{2}{*}{ Personality Types } & Pearson Correlation & 1 & .232 \\
\cline { 2 - 5 } & Sig. (2-tailed) & 30 & .217 \\
\cline { 2 - 5 } & $\mathrm{N}$ & .232 & 30 \\
\hline \multirow{2}{*}{ Writing Ability } & Pearson Correlation & .217 & 1 \\
\cline { 2 - 5 } & Sig. (2-tailed) & 30 & 30 \\
\cline { 2 - 4 } & $\mathrm{N}$ & & \\
\hline
\end{tabular}

Table 12 shows that p-output is 0.217 . This value is higher than 0.05 . So, it is not significant. In this case, $\mathrm{H}_{\mathrm{a}}$ is rejected while $\mathrm{H}_{0}$ is accepted. Therefore, there is not any significant correlation between personality types and writing ability of the eleventh grade students at Senior High School Number 1 Sekayu.

Table 12. Summary of Correlation between Learning Styles and Writing Ability

\begin{tabular}{llrrr}
\hline \multicolumn{4}{c}{ Correlations } & \\
\hline \multirow{2}{*}{ Learning Styles } & & Learning Styles & Writing Ability \\
& Pearson Correlation & 1 & .196 \\
\cline { 2 - 5 } & Sig. (2-tailed) & 30 & .300 \\
\cline { 2 - 5 } & $\mathrm{N}$ & .196 & 30 \\
\hline \multirow{2}{*}{ Writing Ability } & Pearson Correlation & .300 & 1 \\
\cline { 2 - 5 } & Sig. (2-tailed) & 30 & 30 \\
\cline { 2 - 4 } & $\mathrm{N}$ & & \\
\hline
\end{tabular}

Table 13 shows that p-output is 0.300 . This value is higher than 0.05 . So, it is not significant. In this case, $\mathrm{H}_{\mathrm{a}}$ is rejected while $\mathrm{H}_{0}$ is accepted. Therefore, there is not any significant correlation between learning styles and writing ability of the eleventh grade students at Senior High School Number 1 Sekayu.

Table 13. Summary of Correlation between Personality Types and Learning Styles

\begin{tabular}{|c|c|c|c|}
\hline \multicolumn{4}{|c|}{ Correlations } \\
\hline & & Personality Types & Learning Styles \\
\hline \multirow[t]{3}{*}{ Personality Types } & Pearson Correlation & 1 & $.470^{* *}$ \\
\hline & Sig. (2-tailed) & & .009 \\
\hline & $\mathrm{N}$ & 30 & 30 \\
\hline \multirow[t]{3}{*}{ Learning Styles } & Pearson Correlation & $470^{* *}$ & 1 \\
\hline & Sig. (2-tailed) & .009 & \\
\hline & $\mathrm{N}$ & 30 & 30 \\
\hline
\end{tabular}

Table 14 shows that p-output is 0.009 . This value is lower than 0.05 . So, it is significant. In this case, $\mathrm{H}_{\mathrm{a}}$ is accepted while $\mathrm{H}_{0}$ is rejected. Therefore, there is significant correlation between personality types and learning of the eleventh grade students at Senior High School Number 1 Sekayu.

Table 4.14. Summary of Correlation between Personality, Learning Styles and Writing Ability

\begin{tabular}{|c|c|c|c|c|c|c|}
\hline \multicolumn{7}{|c|}{ ANOVA $^{a}$} \\
\hline Model & & Sum of Squares & $\mathrm{df}$ & Mean Square & $\mathrm{F}$ & Sig. \\
\hline \multirow[t]{3}{*}{1} & Regression & 8.692 & 2 & 4.346 & .916 & $.412^{b}$ \\
\hline & Residual & 128.108 & 27 & 4.745 & & \\
\hline & Total & 136.800 & 29 & & & \\
\hline
\end{tabular}

a. Dependent Variable: Writing Ability

b. Predictors: (Constant), Learning Styles, Personality Types 
Table 15 shows that p-output is 0.412 . This value is higher than 0.05 . So, it is not significant. In this case, $\mathrm{H}_{\mathrm{a}}$ is rejected while $\mathrm{H}_{0}$ is accepted. Therefore, there are not any significant correlation among personality types, learning styles, and writing ability of the eleventh grade students at Senior High School Number 1 Sekayu.

Table 15. Regression Model Summary

\begin{tabular}{|l|c|c|c|c|}
\hline \multicolumn{5}{|c|}{ Model Summary } \\
\hline Model & $\mathrm{R}$ & \multicolumn{1}{|c|}{ R Square } & Adjusted R Square & Std. Error of the Estimate \\
\hline 1 & $.252^{\mathrm{a}}$ & .064 & -.006 & 2.178 \\
\hline a. Predictors: (Constant), Learning Styles, Personality Types & & \\
\hline
\end{tabular}

Table 16 shows that coefficient of determination value or $\mathrm{R}$ Square 0.064 or equal to $0.64 \%$. It means that personality types and learning styles variables simultaneously affect the writing ability by $0.064 \%$.

This research was conducted at Senior High School Number 1 Sekayu in Sekayu, Musi Banyuasin in the eleventh grade students. The data of personality types was collected by using questionnaire and the data of learning styles as well. Meanwhile, the data of writing ability is collected by using test.

In answering the first research problem, the result proved that there is not any significant correlation between Personality Types (X1) and Writing Ability (Y). The result rx1y $=0.232$ with $\mathrm{r} 2=0.053824$ (or $0.53824 \%$ ) contributed of personality types, and then the rest is $99.46176 \%$ from other factors. The significant level was $0.217>0.05$, consequently $\mathrm{H} 0$ is accepted. It means that there is not any significant correlation between personality types and writing ability of the eleventh grade students at Senior High School Number 1 Sekayu.

In addition, the second result which is used to answer the second research problem proved that there is not any significant correlation between Learning Styles (X2) and Writing Ability (Y). The result rx2y $=0.196$ with $\mathrm{r} 2=0.00034416$ (or $0.0038416 \%$ ) contributed of learning styles, and then the rest is $99.99961584 \%$ from other factors. The significant level was $0.300>0.05$, consequently, H0 is accepted. It means that there is not any significant correlation between learning styles and writing ability of the eleventh grade students at Senior High School Number 1 Sekayu.

Besides, to answer the third research problem, the result showed that there is significant correlation between Personality Types and Learning Styles (X2). The result rx1x2 $=0.470$ with $\mathrm{r} 2=0.2209$ (or 22.09\%) contributed of learning styles, and then the rest is $77.91 \%$ from other factors. The significant level was gotten $0.009<0.05$, consequently, $\mathrm{Ha}$ is accepted. It means that there is significant correlation between personality types and learning styles of the eleventh grade students at Senior High School Number 1 Sekayu.

The fourth research problems which answering the correlation among personality types (X1(, learning styles (X2), and writing ability $(\mathrm{Y})$ proved that ryx1x2 $=0.252$ with $\mathrm{r} 2=0.063504$ (or $0.63504 \%$ ) contributed of personality types and learning styles, and then the rest is $99.936496 \%$ from other factors. The researcher found that the significant probability is $0.412>0.05$, consequently $\mathrm{H} 0$ is accepted. It means that there is not significant correlation. personality types, learning styles, and writing ability.

The total maximum score of personality type's questionnaire score is 121 . It is on 26 . The minimum score of this questionnaire is 57 . The number of the item is 20 . In addition, the total maximum score of learning styles' questionnaire score is 132 . It is on the sixth item. The minimum score of this questionnaire is 63 . The number of the item is 8 . Whereas, the maximum score of writing ability is on organization part, which is 118 . And, the minimum score is on content, which is 71 . Meanwhile, the average score of personality types, learning styles, and writing ability is $94.19,99.83$, and 99 .

Further, this study found that personality types are not correlated to students' writing because the introverts are not always good in performing their writing ability. This finding is contradictive to [15] found that there is a significant impact on students' personalities to their writing ability. Students with introvert personalities have better writing scores than students with extrovert personality. [13] that all writers are introvert because they have high concentration while completing their woks. Therefore, this study found different finding in the correlation between personality types and students' writing. 
In addition, this study found that learning styles are not correlated to students' writing ability of the eleventh grade students at Senior High School. This finding cons to [14] which proved that there was a weak significant correlation between the students"e learning styles and students' recount writing achievement. So, students' writing performance in recount text is significantly contributed by students' learning styles.

In correlationg personality types and learning styles, this study found that there is significant correlation both these independent varaiables. However, [16] found that there was no significant relationship between the students' learning styles and their personality traits. [17] showed that there was no statistically significant relationship between males and females' learning styles and personality types.

Based on the explanation above, it is found that there was no significant correlation among personality types, learning styles, and writing ability. It is proved that students' personality types and learning styles do not give positive contribution toward students' writing ability. In this research, there were some students who have introvert styles; they did not have good score in writing ability. In the other side, some students who are extrovert, they have good score in writing ability. However, [13] the writers are introvert. There are some factors which influence in writing ability. Also, Kamuche, 2011; Wilkinson, et al., 2013; Kaminski, et al. as cited in Cimermanová (2018) claimed students learning styles could affect their educational performance. However, [18] mentioned that factors which can influence students' writing are classroom management, teachers' strategy, and media used, and material. It shows that the writing ability could be affected by many factors besides personality types and learning styles of the writers.

The explanation above also proved that students are lack of vocabulary and grammar. These aspects become very difficult ones to be applied while writing. Some students made errors in constructing sentences in writing recount text, such as taken which must be took, beauty which must beautiful, etc. In another side, the most frequently happened on students is that they forgot to write the title of their composition and made confusing word forms as wok or work. Thus, students' comprehension of words and language use are still low which cause some errors in constructing sentences.

\section{Conclusion}

The following findings are derived based on the discussion of the study results: (1) There is not any significant correlation between personality types and writing ability of the eleventh grade students at Senior High School Number 1 Sekayu. (2) There is not any significant correlation between learning styles and writing ability of the eleventh grade students at Senior High School Number 1 Sekayu. (3) There is significant correlation between learning styles and writing ability of the eleventh grade students at Senior High School Number 1 Sekayu. (4) There are not any significant correlation among personality types, learning styles, and writing ability of the eleventh grade students at Senior High School Number 1 Sekayu.

\section{References}

Iftanti, E. (2016). A Voluntary Reading Program (VRP) to stimulate EFL reading interest. Indonesian Journal of English Education, 3(2), 192-207.

EF (Education First) EPI (English Proficiency Index). (2017). The world's largest ranking of English skills. http://www.ef.co.id/epi/

Aydogan, H., \& Akbarov. A. A. (2014). The four basic language skills, whole language \& integrated skill approach in mainstream university classrooms in Turkey. Mediterranean Journal of Social Sciences, 5(9), 673-680.

Luchini, P. L. (2010). Evaluating the effectiveness of a complimentary approach to teaching writing skills. International Journal of Language Studies (IJLS), 4(3), 73-92.

Kavaliauskienè, G. (2010). Skills of reading, writing and translating in English for specific purposes. The Buckingham Journal of Language and Linguistics, 3(0), 11-13.

Wallace, H., \& Roberson C. (2009). Written and interpersonal communication: Methods for law and enforcement (4th ed.). Upper Saddle River, New Jersey: Pearson Education.

Choudhury, A., S. (2013). Of speaking, writing, and developing writing skills in English. Language in India, 13(9), 27-32.

Rahayu, A. U. (2015). Differences on language structure between English and Indonesian. International Journal of Languages, Literature and Linguistics, 1(4). 257-260.

American Psychological Association. (2020). Personality. https://www.apa.org/topics/personality/

Holzman, P. (2020, February 24). Psychoanalytic theories. 
Revola, Y. (2016). An analysis of writing achievement among personality type at the third semester students of english department IAIN Bengkulu (Unpublished master's thesis, 2016). State Institute of Islamic Study (IAIN) Bengkulu.

Azzuhria, O. (2017). The correlation between personality types and writing achievement of the undergraduate EFL students of UIN Raden Fatah Palembang (Undergraduate's thesis, State Islamic University Raden Fatah Palembang, 2017). Palembang: State Islamic University Raden Fatah Palembang.

Bearman, S. (2016). Personality theory and your writing. https://writeitsideways.com/personality-theoryand-your-writing/

Surya, S. (2016). The correlation between learning styles and descriptive writing achievement of the eleventh grade students of SMA Negeri 9 Palembang (Master's thesis, Sriwijaya University, 2016). Palembang: Sriwijaya University.

Zaswita, H., \& Ihsan, R. (2020). The impact of personality types on students' writing ability. JPI (Jurnal Pendidikan Indonesia), 9(1), 75. doi:10.23887/jpi-undiksha.v9i1.

Ngatiri, N., R., \& Zainol, Z. (2020). Learning styles and personality traits of computer science undergraduates in Malaysia. The Online Journal of New Horizons in Education, 10(1)

Tahriri, A., Divsar, H., \& Ashouri, F. (2015). The relationship between EFL learners' personality types and their cognitive learning styles. International Journal of Research Studies in Language Learning, 4(2)

Herdi, H. (2015). An analysis on factors influencing the students' writing skill. ELT-Lectura, 2(2). https://doi.org/10.31849/elt-lectura.v2i2.465 